\title{
The Changes in the Policy of Access to the Documents of the Institute of National Remembrance in the Open Government Era in the Context of the Protection of Personal and Sensitive Data
}

\author{
KINGA MAJEWSKA \\ Senior Archivist, Institute of National Remembrance, 7 Wołoska Street, Warsaw 02-675, Poland \\ e-mail: kinga.majewska@ipn.gov.pl
}

The Changes in the Policy of Access to the Documents of the Institute of National Remembrance in the Open Government Era in the Context of the Protection of Personal and Sensitive Data

\section{ABSTRACT}

This paper is going to present the changes in the policy of access to the documents of the Institute of National Remembrance in the period from 2000 until this day in the context of the protection of personal and sensitive data. The paper aims to show the extent to which the policy of access binding in the IPN applies to the guidelines established by the International Council on Archives. To that end, the provisions of access in the IPN have been compared with the Principles of Access to Archives prepared by the ICA. The outline of the changes in the policy of access presented in the paper on the basis on the Act on the Institute of National Remembrance an the Act on the Disclosure of Information confirms unquestionably that the IPN managed successfully to adjust to the Principles and to meet the requirements of the ICA.

Key words: access, Institute of National Remembrance, personal data, sensitive data, principles of access

I cambiamenti nella politica dell'accesso ai documenti dell'Istituto della memoria nazionale nell'epoca del governo aperto nel contesto della protezione dei dati personali e sensibili

\section{SINTESI}

Il presente articolo andrà a presentare i cambiamenti nella politica dell'accesso ai documenti dell'Istituto della memoria nazionale nel periodo fra il 2000 e l'epoca attuale, nel contesto della protezione dei dati personali e sensibili. Il lavoro ha lo scopo di mostrare il livello cui la politica di accesso fissata nell'IPN si applichi alle linee guida stabilite dal Consiglio internazionale degli archivi. A tal fine, le misure per l'accesso dell'IPN sono state comparate con i Principi per l'accesso agli archivi preparati dall'ICA. Il profilo dei cambiamenti nella politica di accesso presentati nell'articolo, sulla base della Legge sull'Istituto per la memoria nazionale e la Legge per la divulgazione, conferma indiscutibilmente che l'IPN ha gestito con successo le modifiche ai Principi in modo da adeguarsi alle richieste dell'ICA.

Parole chiave: accesso, Istituto della Memoria Nazionale, dati personali, dati sensibili, principi per l'accessibilità

Spremembe v politiki dostopa do gradiva Inštituta narodnega spomina v času odprte javne uprave $\mathrm{v}$ kontekstu zaščite osebnih in občutljivih podatkov

\section{IZVLEČEK}

Avtorica v prispevku predstavlja spremembe v politiki dostopa do gradiva Inštituta narodnega spomina v obdobju od leta 2000 do danes v kontekstu zaščite osebnih in občutljivih podatkov. Namen prispevka je pokazati, v kolikšni meri je politika dostopa v IPN skladna s smernicami, ki jih je pripravil Mednarodni arhivski svet. V ta namen smo določbe glede dostopa v IPN primerjali z Načeli o dostopu do arhivskega gradiva, ki jih je pripravil Mednarodni arhivski svet. Oris sprememb glede politike dostopa, ki so predstavljene v prispevku na osnovi Zakona o Inštitutu narodnega spomina in Zakona o razkritju informacij nesporno potrjuje, da se je IPN uspelo uspešno prilagoditi načelom in izpolniti zahteve Mednarodnega arhivskega sveta. 
Kinga MAJEWSKA: The Changes in the Policy of Access to the Documents of the Institute of National Remembrance in the Open Government Era..., 129-136

Ključne besede: dostop, Institute of National Remembrance, Inštitut narodnega spomina, osebni podatki, občutljivi podatki, načela dostopa

Zmiany w polityce udostępniania materiałów zgromadzonych w Instytucie Pamięci Narodowej w kontekście ochrony danych osobowych i danych wrażliwych w dobie Open Government

\section{ABSTRAKT}

Celem niniejszej pracy jest zaprezentowanie zmian w polityce udostępniania dokumentów zgromadzonych w Instytucie Pamięci Narodowej w kontekście ochrony danych osobowych i danych wrażliwych. Zamierzeniem autorki jest również wykazanie w jakim stopniu zasady udostępniania obowiązujące w IPN odnoszą się to wytycznych sformulowanych przez Międzynarodową Radę Archiwalną. W tym celu, regulacje wprowadzone w IPN porównano z Principles of Access to Archives, które zatwierdzone zostały przez ICA w 2012 roku. Zarys zmian w polityce udostępniania przedstawiony w pracy na podstawie zapisów Ustawy o IPN i Ustawy o ujawnianiu informacji o dokumentach organów bezpieczeństwa wskazuje jednoznacznie, że IPN działa zgodnie z zapisami Principles of Access to Archives i tym samym realizuje wytyczne ICA.

Open Government as a $21^{\text {st }}$ century conception, which is to change the functioning of public institutions, assumes that citizens have the right to see, examine, and learn from the records that document the actions of their Government. According to the doctrine, records management is the basis of a transparent and accountable government. The challenges of the changing environment require also the archives sector to be adaptable, flexible and prepared to set new standards and priorities. The requirements of the Open Government Era were also shared by the Institute of National Remembrance in Poland.

The Institute of National Remembrance is an institution established by the Polish Parliament by virtue of the Act of $18^{\text {th }}$ December 1998 (Journal of Laws of 2014, item. 1075) with the aim of taking professional care of the heritage of the communist regime. One of our primary objectives set forth in the above-mentioned law is providing access to the archival resources produced and accumulated by the former security services from $22^{\text {nd }}$ July 1944 until $31^{\text {st }}$ July 1990 and also to the documents of the security authorities of the Third Reich and Soviet Union. The issue of access to these documents was a subject of public debate, which raised a series of questions regarding the rules of dissemination. In the process of laying down the regulations of access, a number of questions had to be taken into consideration: to whom and on what conditions the documents shall be made available and how the personal and sensitive data should be protected, among many others.

This paper is going to present the changes in the policy of access to the documents gathered in the IPN in the period from 2000 until this day. Simultaneously, the paper aims to show the extent to which the policy of access binding in the IPN applies to the guidelines established by the International Council on Archives, whose member the IPN has been since 2011.

In this place it must be stressed that the Principles of Access to Archives (2012) prepared by the Working group on access acting within the Committee on best practices and standard are significant in this respect. The document was accepted by the General Assembly of the International Council on Archives on $14^{\text {th }}$ August 2012 in Brisbane. Until then, there had been two additional ICA documents emphasizing the importance of access as an element of archival practice: the Code of Ethics (1996) and the Universal Declaration on Archives (2010). The Code of Ethics (1996) states in principles 6 and 7: Principle 6. Archivists should promote the widest possible access to archival materials and provide an impartial service to all users. According to Principle 7. Archivists should respect both access and privacy, and act within the boundaries of relevant legislation. Similarly, the Universal Declaration on Archives (2010) underscores that one of the vital roles of archivists is making records available for use and that archivists should work together in order that archives are made accessible to everyone, while respecting the pertinent laws and the rights of individuals, creators, owners and users.

The above-mentioned rules were subsequently elaborated in the Principles of Access to Archives (2012). In the context of the policy of access, which is effective in the IPN, the following guidelines seem to be of primary importance: 
Kinga MAJEWSKA: The Changes in the Policy of Access to the Documents of the Institute of National Remembrance in the Open Government Era..., 129-136

The public has the right of access to archives of public bodies. Public entities should open their archives to the greatest extent possible since access to the archives of government is essential for an informed society.

Institutions holding archives inform about the existence of the archives, including the existence of closed materials and disclose the restrictions that affect the access to the archives. Users must be able to locate the archival institution that holds materials being interesting to them. Archivists provide without charge basic information about their institution and the archives preserved by the institution. They inform the public about the general use of the resources in accordance with the institution's policy. In order to facilitate access they ensure that descriptions are current, accurate and comply with international standards. Archivists provide as much information as possible about restricted material, including the reason for the restriction and the date the materials will be reviewed or become available for access provided that the description does not reveal any restricted information.

Institutions holding archives adopt a pro-active approach to access. Archivists have a professional responsibility to promote access to the archives. To that end they use various means such as Internet and web-based publications, printed materials, public programmes, commercial media and educational activities.

Institutions holding archives ensure that restrictions on access are clear and of stated duration and that they acknowledge the right of privacy. Archivists provide the widest possible access to the archives but they recognize and accept the need for some restrictions, such as the protection of personal data and privacy, safety, national security.

The strong obligation of the ICA to follow the Principles was consequently stressed in the ICA Strategic Implementation Plan 2014-2018 (ICA, 2014)1: [...] archive institutions have the task of providing increasing amounts of information, online through the digitization of archives created on traditional media, at a time when public expectations about the speed and efficiency of information retrieval are constantly rising. At the same time the ICA Strategic Implementation Plan 2014-2018 confirmed the ICA's obligation to take steps in order to adopt its official position regarding protection and preservation of personal data.

The outline of the changes in the policy of access, which has been presented below, confirms unquestionably that the Institute managed successfully to adjust to the above-said principles and to meet the requirements of the ICA.

As it was mentioned at the beginning of this article, dissemination of the materials preserved in the IPN is regulated by the provisions of the Act of $18^{\text {th }}$ December 1998 on the Institute of National Remembrance (Ustawa z dnia 18 grudnia 1998 r. o Instytucie Pamięci Narodowej - Komisji Ścigania Zbrodni przeciwko Narodowi Polskiemu), but also by the Act of $18^{\text {th }}$ October 2006 on the Disclosure of Information on Documents of State Security Agencies from the period between the years 19441990 and the Content of such Documents (Ustawa $z$ dnia 18.10.2006 r. o ujawnianiu informacji o dokumentach organów bezpieczeństwa państwa z lat 1944-1990 oraz treści tych dokumentów), and some internal regulations. The rules of access have been changed several times during the IPN's activity. Generally, there are three legal orders defining form and mode according to which the documents were disseminated to the applicants. In the first period, lasting from June 2000 until March 2007, the access to the documents was provided to the applicants who acquired status of the so-called aggrieved person (i.e. those who were not collaborators, employees or officers of security service agencies). Everyone had the right to apply to the Institute for access to the documents concerning them. The rights could be executed by the closest relatives to the deceased ${ }^{2}$. The applications could be also submitted by the public authorities, institutions, organisations and individuals for the fulfilment of tasks under the Act of $24^{\text {th }}$ January 1991 on veterans and certain persons who were victims of warfare and post-war repres-

1. ICA Strategic Implementation Plan 2014-2018 was approved by the General Assembly in 2014 in Girona.

2. According to the Article 115.11 of the Penal Code, namely: a spouse, ascendant (parents, grandparents, great-grandparents), descendant (children, grandchildren, great-grandchildren), siblings, relative in the same line or degree (in-laws, son-in-law, daughter-in-law, stepson, stepdaughter, stepfather, stepmother, brother-in-law, sister-in-law) provided that the kinship arises on the basis of marriage and continues despite the dissolution of marriage due to the death of the other spouse or divorce, and ceases upon the annulment of marriage. The closest person is also a dependent adoptee and his/her spouse, and the person remaining in cohabitation. 
sions $^{3}$; in the performance of tasks arising from the Act of $11^{\text {th }}$ April 1997 on the disclosure of work or service in state security bodies or collaboration with them between 1944 and 1990 by persons holding public office ${ }^{4}$. The archives were also available for academic research purposes.

Furthermore, employees and officers of the state security agencies had the right to obtain the copies of documents related to their employment or service, i.e. the copies of certificates of service or employment and copies of service or work opinions.

Significant changes concerning dissemination in the IPN were introduced with regard to the amendment of the IPN Act on $15^{\text {th }}$ March 2007 and the entry into force of the Act of $18^{\text {th }}$ October 2006 on disclosing information on documents of state security agencies from the years 1944-1990 and the content of such documents 5 .

The amended provisions ensured that each interested person was provided with access to the documents collected in the IPN. This means that the amended Act abolished the aggrieved party status $^{6}$. The access was also granted to the persons who collaborated with state security agencies. In this case, materials relating to collaboration were excluded from access. Documents were made available in the form of anonymised copies. After submission of a relevant application, the documents were made available in a non-anonymised form (Article 33 (1) of the IPN Act of 2007). Additionally, everyone was granted the right of access to files of employees and officers of state security agencies (Article $35 \mathrm{c}$ (1) of the IPN Act of 2007), files of public persons (Articles 25 - 28 of the Act of $18^{\text {th }}$ October 2006 on disclosing information...) and files of vetting proceedings concluded with a legally valid decision of court (Article 18 (5) of the Act of $18^{\text {th }}$ October 2006 on disclosing information...). In the new Act, the right of access was also provided to public authorities and other institutions, organisations and persons performing their statutory tasks and conducting academic research. Access to archive records was also granted to journalists (Article 36 (1) (1)-(3) of the IPN Act of 2007).

Another amendment to the regulations specified in the Act on the IPN and in the Act on disclosing information on documents of state security agencies from the years 1944-1990 and the content of such documents entered into force on $27^{\text {th }}$ May 2010. According to the Act, the applicants receive originals or copies of documents without prior anonymisation. Only persons with regard to whom the documents confirming their employment, service or collaboration with state security agencies are preserved in the Institute rare entitled only to the copies of the files ${ }^{7}$.

In addition researchers and journalists were given the right to receive (on request) information from data sets, registers and files of state security agencies, including those concerning the identity of secret informers or assistants in acquiring operational information (Article 36 (4 b) of the IPN Act from 2010).

What is important, the primary condition determining the access to the files is filing an appropriate application. All the applications (both in English and Polish version) are available on the IPN's website (Institute of National Remembrance, 2016).

The above described changes in dissemination of the files in the IPN constitute clear evidence that the Institute follows the guidelines prepared by the International Council on Archives in respect to open access policy. It might be stated that current regulations binding in the IPN are in accordance with the content of Principle 1 listed in the Principles of Access to Archives (2012) accepted the General Assembly of the International Council on Archives on $14^{\text {th }}$ August 2012 in Brisbane, i.e: The public has the right of access to archives of public bodies. Public entities should open their archives to the greatest extent possible since access to the archives of government is essential for an informed society.

Another important issue, which has also evolved to a great extent in the course of IPN's activity,

3. Journal of Laws of 1997, No. 142, item 950, as amended.

4. Journal of Laws of 1999, No. 42, item 428, as amended.

5. Journal of Laws of 2007, No. 63, item 424 and 425.

6. Article 6 of the IPN Act of $18^{\text {th }}$ December 1998 defining the term "aggrieved party was repealed (Journal of Laws of 1998, No. 155, item 1016).

7. In such a case, documents are made available in the form of copies by administrative decision against which appeal is available - see Article 31 (1) - (2) of the IPN Act of 2010. 
Kinga MAJEWSKA: The Changes in the Policy of Access to the Documents of the Institute of National Remembrance in the Open Government Era..., 129-136

is protection of personal and sensitive data. It must be stressed that two problems had to be taken into consideration at the moment of establishing the Institute: protection of personal data on the one hand, and providing the broadest possible access to the archives on the other hand.

At the beginning of IPN's operations it was of primary importance to prevent unauthorised access to documents containing sensitive information. To that end, several restrictions aimed to provide protection against access by unauthorised persons were introduced. It was the more important that no grace period was specified to provide an opportunity to exclude certain categories of documents from access.

According to the first version of the IPN Act of December 1998 the Institute was responsible for the protection of personal data of "aggrieved parties" persons or third parties could be made available to the public authorities, institutions, organisations and persons for the purpose of: implementation of the Act of $24^{\text {th }}$ January 1991 on veterans and certain persons being victims of repressions of the wartime and post-war period; implementation of the vetting act, prosecution of Nazi and communist crimes and conducting scientific research on the condition of the consent granted by the President of the IPN.

At the same time, a person who was granted the ,aggrieved party” status was guaranteed the right of restriction of personal data acquired secretly in the course of operational actions by state security agencies and that they would not be made available for research purposes, but not longer than 90 years from the date of their creation (Article 37 (1) of the Act of 18th December 1998 on the Institute of ...). In addition, the legislature granted the aggrieved party extensive decision-making powers regarding the consent to make documents with information concerning the party available to designated persons or institutions (Article 37 (2) of the Act of 18th December 1998 on the Institute of ...). The responsibility for the mode of using the personal data was transferred to the person to whom the documents were made available. Furthermore, the information obtained for research and publication purposes on the basis of documents preserved in the IPN must have not been used for any other purposes or transferred to other institutions (Article 44 of the Act of 18th December 1998 on the Institute ...). Pursuant to the provisions of Articles 31, 36 and 37, the Institute was obliged to notify the aggrieved person about the transfer of his/her personal data to other persons or institutions and inform about the kind of transferred data and their recipient (Article 41, par. 1 of the Act of 18th December 1998 on the Institute ...)

Significant changes in the protection of personal and sensitive data were connected with the amendment of the IPN Act on $15^{\text {th }}$ March 2007 and the provisions of the Act of 18 October 2006 on disclosing information on documents of state security agencies from the years 1944-1990 and the content of such documents. According to the new law any person who has gained access to documents concerning him/her and with regard to whom there are no existing documents confirming collaboration, work or service in state security agencies may reserve that his/her personal data collected in a secret manner in the course of operational activities of state security agencies will not be made available for research and journalistic purposes for a certain period of time, however not longer than 50 years from the date of their creation (Article 37 par. 1 of the IPN Act of 2007). In the first IPN Act the period amounted to 90 years.

What is important, persons who were put under surveillance by communist services may also reserve that the information concerning them that reveal their ethnic or racial origin, religious beliefs, denomination and data about their health, sexual life and financial position, in particular those describing real property and movables recognised as cultural property, will not be made accessible at all (Article 37 par. 2 of the IPN Act of 2007). The duty of the President of IPN is to inform any person having access to documents referring to him/her that he/she is entitled to reserve access to this kind of data.

What has to be stressed in this place is that persons who collaborated with state security agencies are not entitled to reserve access to their personal and sensitive data.

In order to protect sensitive data, which have not been restricted according to the above-men-

8. The persons who were not collaborators, employees or officers of state security agencies. 
tioned regulations, the IPN acts under provisions specified in the Constitution ensuring legal protection of private and family life, honour and reputation (Art. 47 and 51 of the Polish Constitution of 2nd April 1997). What is more, protection of personal property is guaranteed on the basis of Article 23 of the Civil Code. Therefore, sensitive data, which are not restricted according to the IPN's law, are excluded from access on the basis of the above-mentioned provisions. In such cases, documents disseminated for research and journalistic purposes are available only after anonymisation of sensitive data. This practice refers also to personal files of officers or employees of state security agencies especially if they include personal data of any third parties (e.g. family members).

In spite of the fact that provisions of the Act on the Protection of Personal Data do not apply to the IPN's activity, the Institute is obliged to protect personal data of persons to whom documents collected in the IPN refer (Article 1 par. 3 of the IPN Act). The aforementioned procedures ensuring protection of personal and sensitive data comply with Principle of Access 4 established by the ICA, which reads as follows: Institutions holding archives ensure that restrictions on access are clear and of stated duration and that they acknowledge the right of privacy. Archivist provide the widest possible access to the archives but they recognize and accept the need for some restrictions, such as the protection of personal data and privacy, safety, national security.

On the basis of Principles of Access 2 and 3 of the ICA, institutions holding archives should inform society about their existence and provide users with current and accurate descriptions of the files. Moreover, the institutions have a responsibility to adopt a pro-active approach to access. They should also promote access to the archives through various means such as Internet and web-based publications, printed materials, public programmes, commercial media and educational activities.

Taking into consideration Principle 2 and 3, it has to be stressed in this place that the Institute undertook a number of initiatives aiming to promote and to make available the information on the documents preserved in its resources to the public.

Firstly, in all reading rooms located in the headquarters and in the branches throughout the country is available a database including descriptions of archival resources preserved in the Institute. The database, being an electronic inventory of the files, is a part of a broader project aiming to modernize operations of the IPN's archival department called Digital Archive. The database Digital Archive was designed in order to improve access to the IPN's resources and to shorten the time of awaiting for a particular unit ordered by an applicant. The system allows the user to do research on his/her own and provide him/her with a detailed description of the documents at the level of a particular file. Another database facilitating access to archival materials is called "ZEUS" and it is devoted only to audiovisual materials. The system provides a highly developed description of photographic cards, albums, film fragments or non-typical photographs, beside the classic photographs.

The Digital Archive database is available in reading rooms, however, there is also a possibility to analyze the content of IPN's collections via Internet. According to the amendment to the Act on IPN from March 2010 the President of the Institute of National Remembrance was obliged to prepare and publish an "inventory" describing the resource archive going down to the level of archival unit, which certainly was an important innovation in the delivery of policies on open access to documents produced and collected by the communist secret services. The Archival Inventory is accessible on the IPN's website (Inventarz archiwalny, 2016). The users of Archival Inventory have two ways of searching: by the full-text search engine and by the so-called structural search engine. The first one enables to search for the issues, persons, cases, problems mentioned in the archival materials. The second one allows to look through descriptions assigned to the selected section of the archive, then to the archival fond (collection) or its structures according to which the documents have been organised. To help users with better understanding of archival descriptions of particular files, the inventory provides users with the information on the institution which created the files, which was the history of that institution, which is the specificity of the files etc.

Another example of publishing by the IPN of information from the files produced by state security agencies are catalogues containing information on documents concerning public persons, employees and officers of state security agencies, members of the party nomeklatura and oppressed persons. Only in the case of those last-mentioned consent is required for the publication of personal data together with information on the files preserved. The other three categories are published automati- 
Kinga MAJEWSKA: The Changes in the Policy of Access to the Documents of the Institute of National Remembrance in the Open Government Era..., 129-136

cally, without asking those concerned for consent (Article 52 a (6) - (8) of the IPN Act of 2007 and Article 22 of the Act of $18^{\text {th }}$ October 2006 on disclosing information...). The Institute was obliged to publish these catalogues under Article 52a of the amended Act on the Institute of National Remembrance. Initially, the law obliged the Institute to publish a catalogue of secret collaborators, however, the ruling of Constitutional Tribunal of 11 May 2007 considered the creation of such a catalogue as unconstitutional. The catalogues are available on the Internet (Biuletyn Informacij Publicznej..., 2007).

\section{Conclusions}

Archives of the former security state agencies consist an important source of knowledge about the past, therefore, the need to provide the widest possible access to the materials documenting communist regime is so crucial. After 1989 the archives of the Ministry of Internal Affairs and the Office of State Protection preserving the files of the communist secret police were virtually closed for the general public. The establishment of the Institute, which took over the files of communist secret services, enabled scientists, journalists as well as other entitled persons to have access to the documents. This had a profound impact on Polish historiography - researchers were given an opportunity to examine the issues, which until then had been forbidden on account of political circumstances. In a broader sense, the access to the archives and the knowledge about the crimes of the dictatorship play a key role in the process of coming to terms with the past. This in turn should support democracy and enable respect for human rights. All the values seem to be of primary importance for international archival community, including the International Council on Archives. The significance of these values was manifested in the Principles of Access to Archives, which the Institute of National Remembrance has been seeking to follow.

\section{References}

Biuletyn Informacij Publicznej (2007). Available at http://katalog.bip.ipn.gov.pl. (Accesses May 2016).

Code of Ethics, International Council on Archives, 1996.

ICA Strategic Implementation Plan 2014-2018, 2014.

Institute of National Remembrance, (2016). Available at http://ipn.gov.pl/en/archival-records/access-to-resources (Accessed May 2016).

Inwentarz archiwalny /The Archival Inventory (2016). Available at http://inwentarz.ipn.gov.pl. (Accessed May 2016).

Konstytucja Rzeczypospolitej Polskiej z dnia 2.04.1997 r. (Dz. U. z 1997 r. Nr 78, poz. 483).

Principles of Access to Archives, International Council on Archives, 2012.

Universal Declaration on Archives, International Council on Archives, 2010.

Ustawa z dnia 11.04.1997 r. o ujawnieniu pracy lub stużby w organach bezpieczeństwa państwa lub wspótpracy z nimi w l. 1944-1990 osób petniących funkcje publiczne (Dz. U. z 1999 r. Nr 42, poz. 428, z późn. zm.).

Ustawa z dnia 18 grudnia 1998 r. o Instytucie Pamięci Narodowej - Komisji Ścigania Zbrodni przeciwko Narodowi Polskiemu (Dz. U. z 2014, poz. 1075).

Ustawa z dnia 18.10.2006 r. o ujawnianiu informacji o dokumentach organów bezpieczeństwa państwa z lat 19441990 oraz treści tych dokumentów (Dz. U. z 2007 r. Nr 63, poz. 425, z późn. zm.)

Ustawa $z$ dnia 24.01.1991 r. o kombatantach oraz niektórych osobach będacych ofiarami represji wojennych i okresu powojennego (Dz. U. z 1991 r. Nr 17, poz. 75, z późn. zm.).

Ustawa z dnia 6 czerwca 1997 r. - Kodeks karny (Dz.U. 1997 Nr 88, poz. 553).

\section{SUMMARY}

This paper is going to present the changes in the policy of access to the documents of the Institute of National Remembrance in the period from 2000 until this day. Simultaneously, the paper aims to show the extent to which the policy of access binding in the IPN applies to the guidelines established by the International Council on Archives, whose member the IPN has been since 2011. The Institute of National Remembrance is an institution established by the Polish Parliament by virtue of the act of 18 December 1998 with the aim of taking 
Kinga MAJEWSKA: The Changes in the Policy of Access to the Documents of the Institute of National Remembrance in the Open Government Era..., 129-136

professional care of the heritage of the communist system. One of our primary objectives is providing access to the archival materials produced and accumulated by the former security services from July 22, 1944 until July 31, 1990 and also to the documents of the security authorities of the Third Reich and Soviet Union. The issue of access to the IPN's archives was a subject of public debate, which raised a series of questions regarding the rules of dissemination. In the process of laying down the rules of access a number of issues had to be taken into consideration, to whom and on what conditions the documents shall be made available and how the personal and sensitive data should be protected, among many others. The provisions of open access should be considered primarily in the light of the Act on the Institute of National Remembrance dated 18 December 1998 and the Act on the Disclosure of Information dated 18 October 2006. At the beginning of the IPN's activity the access to the documents by persons whom they did not concern was restricted by a number of conditions, which made it impossible, e.g., for researchers to make use of all documents they were interested in. At that time, personal information and sensitive data as well as secret information were protected carefully. It must be stressed that the evolution in the law and regulations in respect of the documents containing personal and sensitive data resulted eventually in the broader access to these materials and more liberal rules, which currently apply to the provision of access.

Typology: 1.02 Review Article

Submitting date: 29.01 .2016

Acceptance date: 20.02 .2016 